DOI: 10.17707/AgricultForest.62.4.26

\author{
Marta VUKOTIĆ LAZAR \\ and Svetislav G. POPOVIĆ
}

\title{
ORGANIZED PROVISION OF GREENERY IN BELGRADE IN ORDER TO UPGRADE THE QUALITY OF LIFE WITHIN THE CITY
}

\section{SUMMARY}

This work is the outcome of the long-time experience in urban planning and architecture of Belgrade and consequently accomplished researches concerning the beginnings and development of the organized provision of Belgrade's greenery.

Urban planning in Europe takes a new course in the $19^{\text {th }}$ century, conditioned with the sudden transformations in the economic and social structures of cities, impelling accelerated development of industries and transportation. Characteristics of urban planning of that time are reconstructions of the old city entities (reconstructions of the existent cities) and their sprawl (planning of the new cities), permanently marked the architecture of Serbia of that period. Induced by the abrupt and uncontrolled urbanization, the second half of the $19^{\text {th }}$ century was characterized by the increased perception concerning the importance of environmental preservation and increased need to develop city greenery, parks, sports and children playgrounds, also of the development of forest parks and weekend getaways. Besides, induced with the modern planning from the end of the $19^{\text {th }}$ century, urban legislation - subject matter of the research - has been developing and improving ever since. In that sense, along the lines of this Work, the attention was directed not only towards the changes taking place in the design of the space by interaction of natural and human factors - significant for understanding of human communities and organization of social life in general - but towards the lives of the pioneers of this profession, public activists and 'hygienists', as Maksimović (1974) called them - towards their tireless missionary work and persistence in their struggle for the revival of the old and in building of the new, healthier cities - Emilijan Josimović (Stara Moldava, 1823 Soko Banja, 1897), first Serbian urban planner and Aleksandar Krstić (Kragujevac, 1902 - Beograd, 1980), horticulture engineer and the first Serbian garden designer. The first worked in the second half of the $19^{\text {th }}$ century, and the second between the two world wars and after the Second World War. Time limit of the research period is between the years 1867 and 1941.

Keywords: urban planning, horticulture, sustainable development, heritage, Emilijan Josimović, Aleksandar Krstić

\footnotetext{
${ }^{1}$ Marta Vukotić Lazar, (corresponding author: marta.vukotic@gmail.com), Faculty of Philosophy University of Priština with temporary Head Office in Kosovska Mitrovica, Department of History of Art FilipaVišnjića b.b., 38220 Kosovska Mitrovica, SERBIA, Svetislav G. Popović, Faculty of Architecture Podgorica - University of Montenegro, Bulevar Džordža Vašingtona b.b., 81000 Podgorica, MONTENEGRO.

Notes: The authors declare that they have no conflicts of interest. Authorship Form signed online.
} 


\section{INTRODUCTION}

As a contribution to the studying of the beginnings in the organized provision of greenery, the intention of the Work is to stimulate the past development research in this field, Also to contribute to the clarification of life and work of certain authors. because their opus is the inexhaustible source of knowledge, significant not only for preservation of cultural heritage, but for the development of different elements of the urban space in general and for the most up to date question - sustainable development (Stovel: 2003; Jokileto: 2014; Jokileto: 2015; Nikolic: 2015; Vujcic et al.: 2016).

Its intention is to open numerous questions and to show how very important is the studying of a city past as well as of the history of the urban planning ideas and initiatives, within the context of the pioneers' opus, including their progressive tendencies in the history of the urban planning thoughts and practice, initiators of the organized care about greenery in these spaces. The Work presents and analyzes the First Urban Plan of Belgrade from 1867, with special emphasis on the green belt of Belgrade - Emilijan Josimović, the first Serbian urban planner in the second half of the $19^{\text {th }}$ century, as well as the work of Aleksandar Krstić, horticulture engineer and the first Serbian garden designer, important not only for the period between two wars, but for the period after the Second World War till the end of 1970's (the work is dealing with his opus between the wars).

A comprehensive published material - books, texts, studies and newspaper articles, as well as cartographic and planning documentation - has been collected and analyzed - direct testimony about the researched periods of these two pioneers of contemporary urban planning theory and professional achievements. Their work was viewed within context of the new standards in planning and construction, as well as environmental regulations, demands unification of the complete constructions law. With their big knowledge and experience, these two tireless professionals left the permanent mark not only in Belgrade, but everywhere in the ex Yugoslav space, where their work later had numerous and fruitful followers.

The goal of the research was not exclusively making chronology of events within the given marginal years of the researched period, though also clarification and comprehension of connections and relations the events from the past are transferring, not only within the given limits but beyond, up till today. Professional-scientific sustainability of the research for this paper reflects in consideration of the first urban plan in Serbia, Emilijan Josimovic (Stara Moldava, 1823 - Soko Banja, 1897) in the context of Belgrade's green belt, and activity of Aleksandar Krstić (Kragujevac, 1902 - Beograd, 1980) in relation to the lessons of this $19^{\text {th }}$ century plan, during many years of his work in design, reconstruction and realization of the great number of Belgrade's parks, squares and alleys. Modifications in shaping the space as the elements of social changes, also the creative work of the pioneers of Serbian urban planning and organized greenery of Belgrade care were also elaborated. The special review was given 
concerning their books, studies and texts, published in newspapers and periodicals, impossible to be avoided while dealing with the history of urban planning and horticulture in these spaces.

Induced by modern planning up till the end of $19^{\text {th }}$ century, urban legislation has been developing and improving, also the subject matter of this paper.

\section{MATERIAL AND METHODS}

In function of the integral consideration of the subject matter and achievement of the given goal of the research, several scientific methods were used systematically as the benchmarks for the research procedure used to check out proposed hypothesis. Historiographical method was applied, harmonized with the subject matter and goals of the research. The focus of the work has been the collection, classification, systematization and analysis of the archives' materials (plans, old photographs, drawings, documents, correspondence, etc), also of the published materials (laws, bylaws, regulations, registers, etc.), as well as published periodicals and literature from the period within the given time of the research, though from the earlier period as well.

The research (collecting of materials and data) was carried out in museums, libraries, archives, specialized institutions, urban planning and geodetic institutes, etc. A comparative analysis was applied in order to compare activities of the authors, pioneers of the organized care about the greenery of Belgrade, with special emphasis on Emilijan Josimović and Aleksandra Krstić, aiming to make objective conclusions and correct valorization of their contributions to the development of urban planning in Belgrade, with special review of their contribution to the organized care of the greenery of Belgrade.

By using the method of critical analysis, the checking out and founding of the given hypothesis and results of the research has been carried out. As an ultimate result of the research and analysis, the conclusions about the work of Emilijan Josimović and Aleksandar Krstić has been made, the first in the second half of the $19^{\text {th }}$ century and the second in the $20^{\text {th }}$ century, about their work, place and part in the development of Belgrade. The significant knowledge is that each of the authors implemented the elements of personal attitude and creativity in his own projects, not for a moment violating the precisely defined rules of constructions, with a stronger legal foundation in the defined period. All the things done made a more complete picture about their significance and their pioneer work in the beginnings of the organized development of the Belgrade's greenery, and the intention of work is to present these results.

\section{RESULTS AND DISCUSSION}

Judging by today's matrix of the city with few preserved public building from the period of Turkish reign (period of Otoman Impery), it is not easy to conclude that Belgrade was a significant settlement of the ottoman empire, with population of almost 100,000 and with characteristics of the eastern town (mosques, caravanserais, bezistans, amams, etc). Buildings from that period were 
mostly demolished during Austro-Turk wars in $17^{\text {th }}$ and $18^{\text {th }}$ century, the others dilapidated because of the friable construction material, and those lasted up till the 19th century were demolished after the liberation of the cities in Serbia (Đurić - Zamolo: 1977). The lack of plans for the first half of the $19^{\text {th }}$ century is illustrated with the fact that only less than twenty plans is known in that period in comparison with more than hundred plans in the last decade of the century. Among these scarce plans 'measuring of the alleys' from the beginning of the $19^{\text {th }}$ century, a special place is reserved for the five fragmentary sketches, connected with the choice of certain sites, land use and new streets layouts, signed all by Frantz Janke, the Slovak (places and years of birth and death unknown; who lived in Belgrade from 1834 - 1843) "pravitelstveni indžinir" of the prince Miloš Obrenović, also the designer of the various significant buildings in Belgrade at the time, constructions were the messengers of novelties from the west, indicating all together intensive planning activity in that period (Đurić Zamolo: 1981). From that period is also the precious cartographic document "Turkish plan of the city and the borough in the trench" from 1863, kept in the national library of Serbia, the plan containing 172 different structures and localities in Belgrade, as well as all the registered houses in the city with the ethnicity of the owners - residents. It was politically covered, precisely with the special use to show ethnicity and ownership in different parcels for the borough within the trench (Golubović: 2006).

In that period great merit for the development of greenery in Belgrade and its surroundings belong to Atanasije Nikolić (Bački Brestovac, 1803 - Beograd 1882), the associate and the man of confidence of the prince Mihailo Obrenović and Ilija Garašanin, lyceum professor and a distinguished engineer. He has been lecturing agriculture from 1840, and founded in 1853 agricultural (zemljodelsku) school in Topčider aimed to improve it. Up till 1859 when it ceased to exist, more than 200 students graduated this school. In that place Nikolić created the experimental estate and planted Topčiderski Park. He initiated the edition "Poljoprivredni list" and wrote manuals to be used in the lecturing of Zemljodelska school (crop farming, grape growing, fruit growing, forestry, etc.). He elaborated concept designs for the Topčider park, Košutnjak and fruit nursery garden in Topčider (flooded fen in 1850), and started planting of numerous alleys along the streets of Belgrade, decorating Terazije with multiple lines of chestnut trees and in the streets Kneza Miloša, Abadžiska and Ministarska with poplar trees, existing in Topčider road even today (Šolaja and Magdić: 1994; Šolaja : 1995).

Adopting of the legal and later planning regulations - despite tough economic and social conditions - will influence not only the development of urban planning and construction, though also the overall cultural life in Serbia. Towns will gradually acquire planning regulated structures, dominated by prince' residences - konak, courts, private houses, mehana, schools, quarantines, etc. A set of law and bylaws was adopted in 1860' regulating urban planning and settlements. Two laws adopted 1866 are the most significant: "law on 
settlements" classifying urban type settlement as towns and small towns varošice and the „law on expropriation of the private real estate for public use, with compensation, one of the first such type laws in Europe (Roter - Blagojević: 1998). Founded on these two laws in september 1867 the state council considered "draft law about regulation of the Belgrade town", suggesting establishing of a commission to adopt "new regulation plan of Belgrade town", the aim was to stop previous practice of partial regulation of the city and to establish legal conditions for the implementation of planning regulation in Belgrade. The law could not be adopted due to financial and technical reasons.

The period between 1867 and the beginning of the First World War is exceptionally important for the growth and development of Belgrade. All the street networks, city blocks, squares and parks of the nowadays central parts of Belgrade - with their good and bad characteristics - are coming from this period. The beginning of the period is marked by the final surrender of Belgrade under Serbian rule and elaboration of the first urban plan of the borough in the trench. When the urban planning regulation is in question, significant were modifications of the "law on settlements" from 1866, among them of exceptional importance was the obligation that all the towns and small towns must elaborate their regulation and terrain leveling plans. One article was supposed to define the settlement limits - city territory where construction rules are applied, as well as municipality obligations about communal-infrastructure provision within the territory (Roter - Blagojević: 1998).

In solving out the issues of future development of the old borough in the trench, the main role - legalized on the appointment of the state council and construction ministry - was given to emilijan josimović, professor of mathematics, geodesy and architecture in the gunnery school, lyceum and university professor and the first Serbian urban planner. "Plan of the old Belgrade (part within the trench) as it is now and as it was regulated" from 1867, was elaborated on demand of the prince Mihailo Obrenović and it is the most significant Serbian document for the regulation of Belgrade borough in the 19th century. In urban planning sense, it follows modern European tendencies and trends, deserving for Josimović the honor of the first Serbian urban planner.

Although Josimović' work was connected to Belgrade, it has wider significance, because it became the first example for the reconstruction of the inherited towns in Serbia. His book following this plan titled "the explanation of the suggestion for regulation of this part of the city of Belgrade within the trench with one lithographed plan, the scale 1:3000" (the plan in the end of the book as an appendix), where Josimović wrote and published his understanding of the problem and methods of the reconstruction - the first theoretic urban planning work in Serbia. (figure 1). The importance of Josimović's work for the later development of the urban planning in Serbia is seen in the fact that in the same 1867 the project of "The law on regulation of Belgrade town" was presented to the state council, accomplishing the influence of his work on the creation of the first urban planning law in Serbia. 


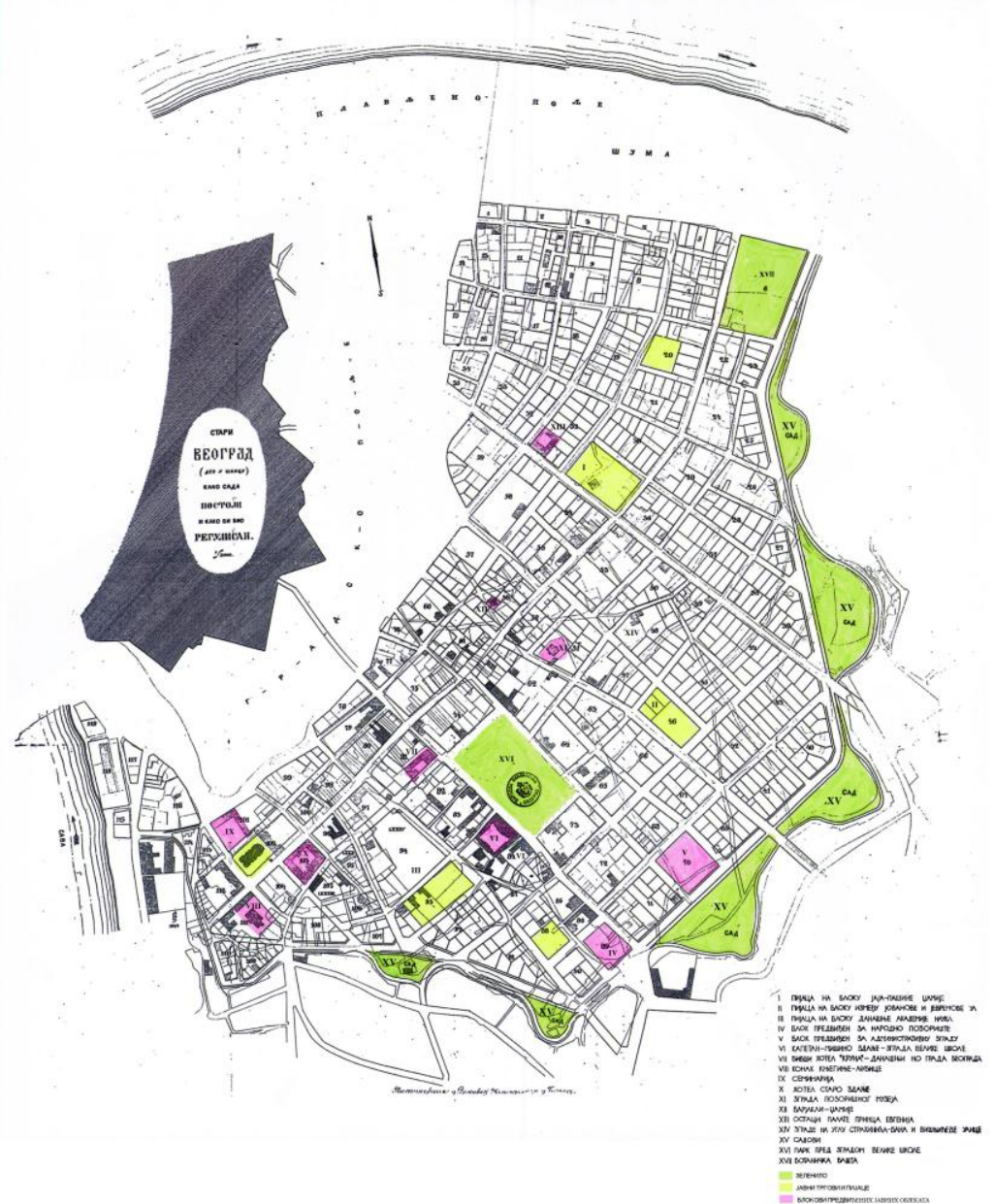

Figure 1. Emilijan Josimović, Old Belgrade (The Area in the Moat) as it is today and as it was regulated, from 1867.

For the reconstruction of the old town, he used the integral analysis of structure - the existent situation - mainly consisting of clearing out of all the drawbacks, elaborated in the chapter of the book titled "City drawbacks - objects of regulation". The procedure applied, in words of Branko Maksimović (1967) only a long time later would become obligatory part or urban planning elaborations and practice. This renown urban planner was suggesting even then making connection of the forest-park belt by the Danube - 250 meters wide - with the Kalemegdan park, and consequently with the Sava riverside. Pointing out natural and geographic position of Belgrade, he thought that the city on the banks of the Sava and Danube, two waterways, must get the key around the town, adjusted to the river transport, as well as the basin dock besides the Danube, main waterway of Europe, in his words. 


\section{0БЈАCHЕШЕ}

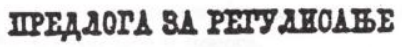

OHOTA AF्य Burorm!

В Е 0 Г Р А Д А,

aro axt 8 and
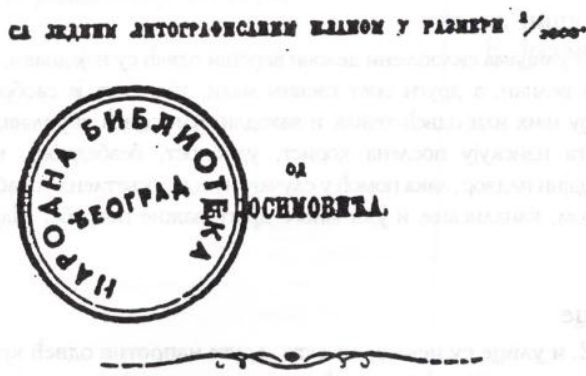

1867.

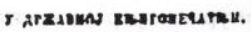

Насловна сйрана „Објаснења..." из 1967. године

Figure 2. Titlepage of the book Justification of the Proposal for regulating the

Area of Belgrade in the Moat with the aid of a lithographed plan, scaled at $1: 3000$.

He was also suggesting sanitization of the Danube riverside area occasionally flooded - considering that the space should be forested with a special kind of trees, succeeding in the wetland. Together with josif pančić, he marked out the two hectares space in that area for the location of the botanical garden.

When the lack of the city greenery was in question, he openly criticized careless treatment of the authorities, giving even credit to turks that they'd paid more attention to it, being taken in that time less as an objective professional opinion, and more as an insult (Terzić: 1994). He was suggesting refilling and 
leveling of the trench spreading around the old town and that the old Belgrade would be later encircled from the Sava to Danube with venci, planted alleys, with separate pathways for pedestrians, cart and riding transport. Suggested seven garlands ("sedam venaca") were spreading two and half kilometers long, today left only three of them: Obilićev, Topličin and Kosančićev venac. The green belt around the old town had in his opinion double importance, first, the city would get belts of parks of around 50.000 square meters, and second, such a belt would preserve historical contour of the Belgrade trench, partially preserved even today in the broken directions of the three preserved city garlands and towards the Danube with the line of Skadarska street. Josimović also suggested that Kalemegdan should be developed as the city park, as well as the space of Velika pijaca (Big market - Students square nowadays), and from the six suggested smaller parks in Belgrade, only two were realized - in Topličin venac and in front of the house of the army of Serbia. His visionary and the most courageous suggestion was the tunnel under Kalemegdan what would enable convenient and fast connection between the Sava key and the Danube port (Maksimović: 1967).

Although neither many of his ideas nor the street network of the borough in the trench were not completely realized as he imagined them in 1867, the essence of the Josimović solution was preserved and witnesses about the first and strong steps towards modernization and europeanization of Belgrade.

Up till the end of the first world war

Construction works in Belgrade were in accordance with regulation plan and in the limited construction territory. After the war, destroyed and demolished city became the capital of the kingdom of Serb, Croats and Slovenes (SCS), and later kingdom of Yugoslavia (1929). First years after the liberation were characterized by clearing the terrain, rehabilitation and construction works, and in the same time the city was facing uncontrolled population increase. The fact that all the state institutions and administration of the new kingdom were concentrated in Belgrade as the capital, the abrupt population growth was highly expected. General urban plan of Belgrade adopted after the international open competition in 1924, and then the other known as the "Obradović' regulation plan of Belgrade" from 1927, were incapable to follow growth and development of Belgrade. While the plans were adjusting to the various demands and circumstances, the city was shaping spontaneously, regardless of the plans, according to the wishes of its inhabitants. So called "informal construction" became one of the immediate problems. Belgrade started to sprawl towards its hills, where the land was cheap, though without infrastructure - streets pavement, lighting, sewerage, etc. Despite the big and numerous obstacles, during the period 49 settlements of various types were founded in: Karaburma, Pašino Brdo, Dušanovac, Voždovac, Banjičko Selo, Topčidersko Brdo, Mihajlovac, etc. (Ćorović: 2009). In order to stop and prevent "informal constructions" during 1923 - 1929 period, preparations for the design of various regulation plans were carried out: Topčider, Košutnjak, Bulbuder, Laudanov Šanac, Pašino Brdo, Voždovac, Čukarica and Marinkova Bara, as well as the outskirts of Belgrade. It 
was also the period of elaboration of the general urban plan and of solving out numerous issues in the city by using the urgent procedure. Those were the years when the concept of living known as "Garden city" according to the idea of Howard Ebenezer was promoted in the capital for the first time, as well as the idea of modern architecture and its socioeconomic significance. In the suburban parts of Belgrade "colonies" and "koteži" started to grow (both terms are synonyms for the improvement of the quality of housing and life in general), and the first settlement founded in Belgrade according to the principle of "Garden city" was "Kotež neimar" (1924 - 1930).

\section{In the period between two world wars}

From the very start the authorities adopted the policy that the issue of the parks development (public and private) was in the close feedback with the regulation, growth and development of the city. A modern urban regulation, concerning health care and aesthetics, is impossible to plan without sufficient city greenery (Maksimović: 1930). Even then, ,housing hygienic" got a new and important dimension. Belgrade municipality - via the "department for parks and forestation" - worked a great deal to promote this issue. Greenery ceased to be treated only as a part of communal activities, but with its role for embellishment, recovery and upgrading of settlements, more precisely for life in general. Unoccupied space was treated as "fresh air reservoirs" planned to be accessible and available to the citizens in any moment, and only a small number of the public parks areas was - for security reasons - planned to be closed by night (glass gardens, botanical garden, zoo, etc.).

Construction law (1931) and Construction rulebook (1935), regulate relation between horizontal projection constructed and the total area part of a lot (index of occupancy). The rulebook definitely determined that proportion for the particular zones, what was of vital significance for individuals, owners, also for communal, hygienic and esthetic issues in the large sites of the very important and expensive city construction land properties. Municipal authorities was taking care of the communal equipment of every square meter in its territory, leaning primarily on law enforcement, and also using propaganda, appealing on civic consciousness and other similar methods. The shortage of parks, children playgrounds and sports grounds has been for years a grave city problem. Visionary concepts of Emilijan Josimović about the pars belt around the old Belgrade town were left unrealized, though after the first world war municipal authorities made the decision to make all the necessary steps to realize numerous ideas concerning the city greenery, not leaving them aside anymore.

Natural position of the main promenade in Kalemegdan, encouraged the authorities to initiate its extension, in order to develop a new terrace in the lower level, connected by the staircase with it, giving Kalemegdan park a good connection with the fortress (1928-1930). "concept design of the sava promenade with big staircase in Kalemegdan" is the work of Aleksandar Krstić (Kragujevac, 1902 - Beograd, 1980), horticulture engineer and the first Serbian garden 
designer and longtime head of the department of parks and reforestation in the Belgrade municipality, who was later the chief manager of the city greenery and economy. In the period when he worked in the department of parks and foresting, as well as after the Second World War, for almost twenty years Aleksandar Krstić was designing, reconstructing and developing most of Belgrade parks, squares and alleys (the area around Serbian national assembly, Kalemegdan, Topčider park, Voždovac park, etc.). He stays in the similar positions after the war (directorate general for spas of NR Serbia, park service; head of the biological-technical service in the institute of hygiene of NR Serbia, and from 1953 he was professor in academy of applied art. His significant works from the period are numerous spas in Serbia, memorial cemetery of the liberators of Belgrade, development of national parks Lovćen and Durmitor in Montenegro, etc.). As the first garden designer, he was the member of association of applied artists and designers of Serbia and was the founder of association of garden experts of Yugoslavia. He spent almost fifty year of th3 200th century working and struggling for his profession. (Milanović: 2006). Air pollution in the second part of the $20^{\text {th }}$ century is multiply increase as the consequence of the equal increase in population of Belgrade, emphasizing significance of greenery for the national health (Vujčić et al 2016.)

Design of the main project with all the decorative details krstić confided to his associate, Đorđe Pavlović Kovaljevski (1888 Jelisavetgrad, Rusija) Russian emigrant and the leading urban planner of the municipality responsible for the general urban plan of Belgrade (Jovanović: 1996). Before the design of "sketch for the new promenade in Kalemegdan (1928)" Kovaljevski had previous experience in the park design during elaboration of "situation plan for the building student dormitory king aleksandar i within Belgrade university (student dormitory "Lola" nowadays) and national library in the park of Ćirilo and Metodije, 1926, scale 1:500. The dormitory as well as the park was realized and today they are still in function.

Never digressing from the basic idea of Krstić, Kovaljevski elaborated and figuratively shaped this sketch, scale 1:100. During realization of the representative tree-part staircase with two platforms, he is adding to it semicircle enlargements to uplift monumentality of the composition. His project was almost completely realized in 1928 .

Upper town in Kalemegdan was opened for the visitors in 1931, the works in the Little Kalemegdan were carried on and the works in the space between the church Ružica and Little Kalemegdan - conceded to the municipality by the army- were initiated. After the demolition of the barracks in 1939, within the city block where the officers' club and the theatre building "Manjež" were situated, the works on the construction of park started, what was partial realization of the suggestion from the general plan 1923, about the opera building within the park space in that particular site. After the First World War the land of topčider court economy and Košutnjak was divided. The biggest par of land with regulated parks and forests was taken over by the Topčiderski park administration, and the 
other smaller part was ceded to the palace complex in dedinje. In August 1924, the Ministry of agriculture and water management announced the "open international competition for the design of the general plan for regulation of Topčiderski park and Košutnjak“. The competition was closed in 1925.That is how this 35 hectares turf space was transformed into the Belgrade's resort. It is connected with Topčiderski park with the old road, as well as with the designed alley, realized in the same time when Dedinje Boulevard was finished and planted with poplar trees. After the building of the "royal palace" and the "new palace" dedinje and senjak have got ,regulation plan“, transforming after a while from suburban area with summer houses, to the space of residential type, planned and used for the elite housing. Today's complex occupies around 130 hectares and the park space covered with rare plants brought from America and Asia, occupies one third of the total area. Around 70 hectares of space, mostly towards the Topčiderska river, is preserved as the forest area (Ivanović: 1993) (fig. 3).

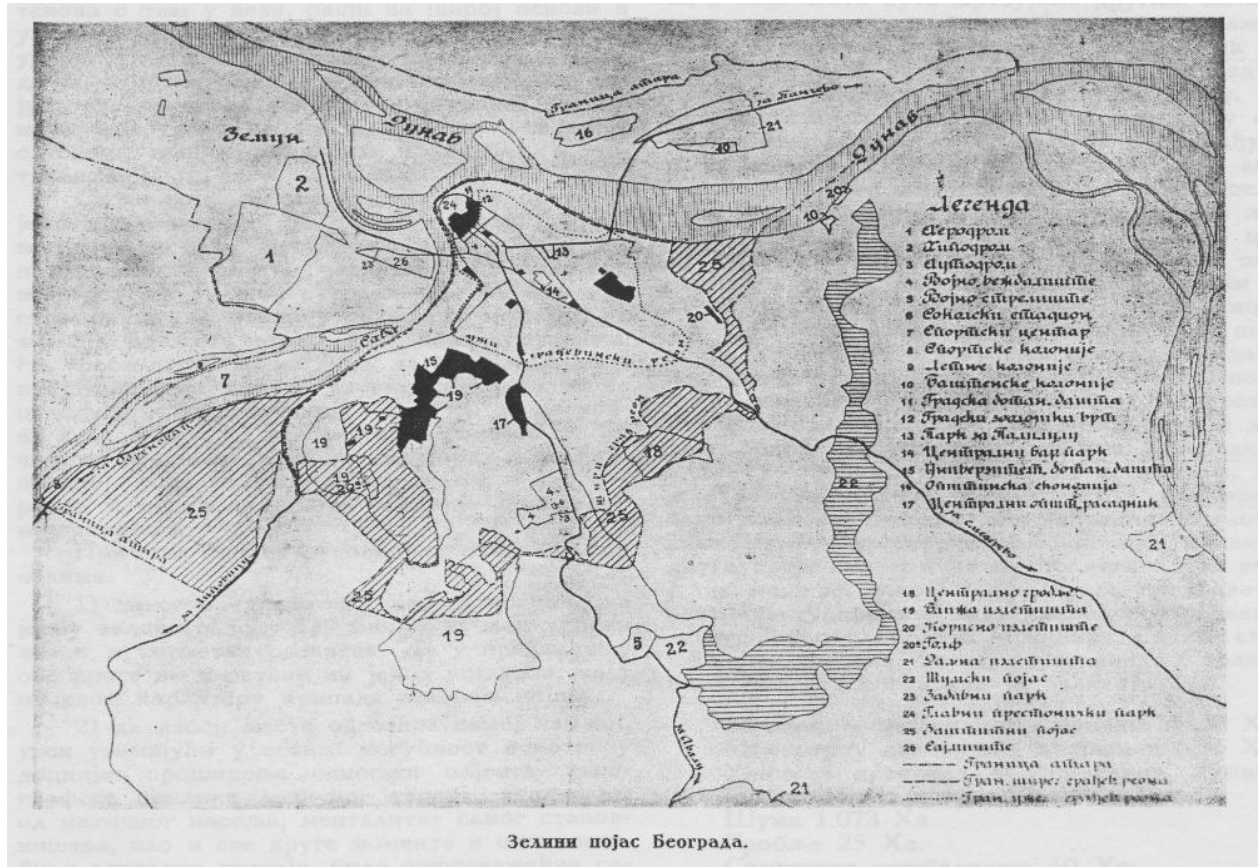

Figure 3. Aleksandar Krstić, Planning Problem of Belgrade and its surroundings. Afforestation and beautification. (Appendix to the text published Aleksandra Krstic in BON no. 10/1936. p.710).

Forestation of Belgrade begins in a greater extent in 1933, when the jurisdiction for these affairs was transferred to the Belgrade municipality "Department for parks and forestation" headed by Aleksandar Krstić. Up till then, these affairs were in the state jurisdiction via "committee for forestation and regulation of the Belgrade's vicinity" (Krstić: 1934). There was no difference and no priorities in forestation of all the parts of Belgrade: on the Danube, in 
Topčider hill, around public housing, Prokop, Mijić imanje, Marinkova forest, at the power plant in banjica, pionir, around public housing in bulbuder, close to elementary schools, at the butchery, etc (Krstić: 1934). Between new constructed parks in 1930s are: "Park prestolonaslednika Petra", park "Manjež", park at "Gospodarska mehana", park in the place of "Velika pijaca", then the park at the new power plant, park in Čubura, Zvezdara, etc. Fourteen squares were also accomplished in the same period and in different parts of Belgrade (at "Tri ključa”, under Dalmatinska street, squares in Palmotićeva street, square Starine novaka street, in Senjak etc.), and also 38 yards of various institutions were finished, with the priority given to schools and children care institutions (school yards, gardens, children playgrounds). Street alleys and gardens were also extensively planted. (Krstić: 1934). Till the beginning of the Second World War, Belgrade had a great number of the open markets (Zeleni venac, Kalenića guvno, Cvetni trg, Smederevski đeram, Bajlonijeva, Palilulska etc.) And it was planned to build a couple of new ones around the city.

Belgrade zoo was opened in 1936 - on the initiative and at the expense of the mayor vlada ilića, engaged during his term of office (1935-1939) with the erection of the big Belgrade's bridges, beautiful constructions, solving out social problems, building of workers' accommodation, health care institutions and children shelters, schools, with filling of the bogs and swamps in the left bank of the sava (beginnings of new Belgrade), foresting and parks building. It was Ilić' wish that the first manager of Belgrade's zoo became aleksandar Krstić - his position till 1941. In that time, the Zoo was twice as big as it is today (figure 4).

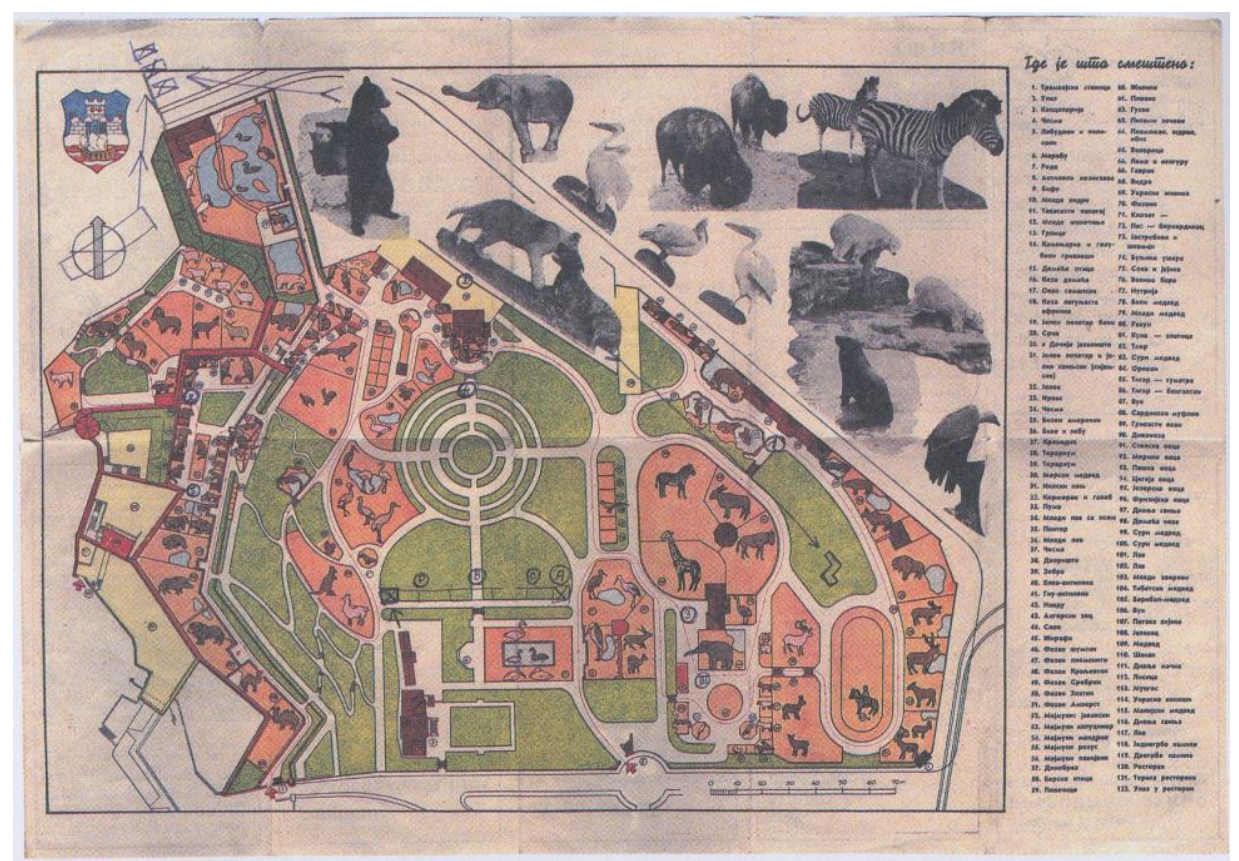

Figure 4. A map of the Belgrade Zoo in 1939 (HAB, Lf.AT). 


\section{CONCLUSIONS}

Founded on the presented data, it is obvious that the planning development of the greenery in Belgrade got its full swing by the end of the 19th century, making a partial shift from the right course with the appearance of illegal constructions till the beginning and shortly after the First World War. The discipline in planning established between two wars had as a result renewed significance of greenery, expressed by the design of the developed green spaces - essential even today - of Senjak, Dedinje and Topčider. This trend is preserved after the Second World War by maintaining and developing greenery as the obligatory component of all the urban plans.

This example confirms the fact that the planning of green spaces and planning approach to this segment gives as a result better quality of life in the cities and higher value of space in general.

\section{ACKNOWLEDGMENTS}

The work is dedicated to Emilijan Josimović, in the occasion of 150 years anniversary frtom the first urban plan in Belgrade elaborated in 1867 - the jubilee $(1867-2017)$ to be celebrated the next year.

\section{REFERENCES}

Corović, Dragana (2009): Vrtni grad u Beogradu. Beograd: Zadužbina Andrejević.

Djuric - Zamolo, Divna (1977): Beograd kao orijentalna varoš pod Turcima 1521 - 1867. Beograd: Muzej grada Beograda.

Djuric - Zamolo, Divna (1981). Graditelji Beograd 1815 - 1914. Beograd: Muzej grada Beograda.

Golubovic, Vidoje (2006): Stari Beograd, topografski rečnik. Beograd: Beosing.

Ivanovic, Milovan (1993): Dvorovi na Dedinju, srpski zabranjeni grad. Beograd: Turistička štampa.

Jokileto, Juka (2014): Ispitivanje univerzalnosti u teoriji konzervacije. Moderna konzervacija no. 2: pp. $11-14$.

Jokileto, Juka (2015): Konzervatorska etika od Rigla do danas. Moderna konzervacija no. 3: pp. $11-24$.

Jovanovic, Miroslav (1996): Doseljavanje ruskih izbeglica u Kraljevinu SHS 1919 1924. Beograd: Stubovi kulture.

Krstic, Aleksandar (1934): Parkovi i pošumljavanje Beograda. BON br. 1 - 3: pp. 257 264.

Maksimović, Branko (1930): Tehnički problemi naših gradova II. Savremena opština no.9-10: pp. $709-716$.

Maksimovic, Branko (1967): Emilijan Josimović, prvi srpski urbanista. Beograd: IAUS.

Maksimovic, Branko (1974): Istorija urbanizma. Novi vek. Beograd: ISC (Izdavačko informativni centar studenata).

Milanovic, Hranisalv (2006): Zelenilo Beograda JKP. Beograd: Zelenilo Beograda.

Nikolic, Marko (2015): Istorijski pregled vodećih ličnosti, ideja i teorijskih dela u oblasti zaštite kulturnog nasleđa u 18. i 19. veku. Moderna konzervacija no. 3: pp. 35 49.

Roter-Blagijevic, Mirjana (1998): Pojava prvih zakonskih propisa i standarda u oblasti građevinarstva u Srbiji tokom 19. i početkom 20. veka. Izgradnja no. 5: pp. 245 258. 
Stovel, Herb (2003): Kulturni pejzaži: novi pristup očuvanju kulturnog nasleđa. Glasnik Društva konzervatora Srbije (DKS) no. 27: pp. $14-19$.

Solaja, Vladimir (1995): Inženjeri Odeljenja (Ministarstva) građevina u Srbiji u XIX veku - jedan presek. Pinus zapisi no. 1: pp. 1-18.

Solaja, Vladimir and Magdić, Adela (1994): Putevi srpskog inženjerstva tokom XIX veka. Katalog izložbe br. 74. Beograd: Galerija SANU.

Terzic, Dusan (1994): Emilijan Josimović vizionar ulaska Beograda u urbanu civilizaciju (romansirana biografija). Beograd: Društvo urbanista Beograda.

Vujcic, M., Tomicevic-Dubljevic , J., Tomicevic-Gavrilovic, D. (2016): The socioeconomic and health effects of green infrastructure on the Vracar municipality, city of Belgrade. Agriculture and Forestry, 62 (3): 165-174. DOI:10.17707/AgricultForest.62.3.14 